\title{
Evaluating the Impact of Risk on Contractor's Tender Figure in Public Buildings Projects in Northern Nigeria
}

\author{
L. O. Oyewobi ${ }^{1}$, A. D. Ibrahim ${ }^{2}$, and B. O. Ganiyu ${ }^{3}$ \\ ${ }^{1}$ Lecturer II, Department of Quantity Surveying, Federal University of Technology, Minna, Niger State, Nigeria, E-mail: \\ oyekunlehassankay@yahoo.com (corresponding author). \\ ${ }^{2}$ Senior Lecturer, Department of Quantity Surveying, Ahmadu Bello University, Zaria, Kaduna State, Nigeria. \\ ${ }^{3}$ Lecturer II, Department of Quantity Surveying, Federal University of Technology, Minna, Niger State, Nigeria.
}

Project Management

Received August 8, 2011; received revisions October 11, 2011; November 9, 2011; November 29, 2011; December 10, 2011; accepted December 11, 2011

Available online December 21, 2011

\begin{abstract}
It has become almost impossible to have projects completed within the initial cost and time in Nigeria; this is as a result of many factors the construction industry is being plagued with ranging from estimating risk to time and cost overruns. The construction industry is widely associated with a high degree of risk and uncertainty due to the nature of its operating heterogeneous environment. The paper aimed at evaluating the impact of estimating risk on contractor's tender sum with a view of ensuring efficient delivery of projects in the Northern part of Nigeria. A survey was conducted using questionnaire and a total of four headings of risk factors were identified. Research findings showed defects in design, inflation, contractor's competence and political uncertainty as well as changes in government had greatest impact on contractor's tender figure whereas likely trend in wages rates over the period, excessive approval procedure in administration government department, unavailability of sufficient amount of unskilled labor and technical manpower and resources of the company were the most significant factors to be considered by contractors when estimating the pricing risk. The paper recommends that construction professionals should identify and adequately quantify project estimating risk factors. Adding a risk premium to quotation and time estimation has to be supported by governmental owner organizations and other agencies in the local construction sector. Competent contractors should be allowed to tender so as to see the incidence of these estimating risks as an important aspect that requires attention while evaluating contractor's tender sum.
\end{abstract}

Keywords: Contractors, construction industry, estimating risk, tender figure.

\section{Introduction}

Risks are an inseparable part of construction project Makui et al. (2009). Risk in construction has been described as exposure of construction activities to economic loss, due to unforeseen events or foreseeing events for which uncertainty was not properly accommodated (Joshua and Jagboro, 2007). Whenever a construction project is embarked upon, there are some risk elements inherent in it, such as physical risk, environmental risk, logistics risk, financial risk, legal risk and political risk among others (Perry and Hayes, 1985). With construction projects becoming increasingly complex and dynamic in their nature as well as the introduction of new procurement methods, many contractors have been forced to rethink their approach to the way that risks are treated within their projects and organizations. Although the construction industry, perhaps more than most industries, is particularly plagued by risk (Flanagan and Norman 1993), the risks are not dealt with adequately, resulting in poor performance with increased costs and time delays (Thompson and Perry 1992).
Common risks faced by contractors include: changes in work, delayed payment on contract, financial failure of owner, labor disputes, labor, equipment and material availability, productivity of labor, defective materials, productivity of equipment, safety, poor quality of work, unforeseen site conditions, financial failure of contractor, political uncertainty, changes in government regulation, permits and ordinances, delays in resolving litigation/arbitration disputes, inflation, cost of legal process and force majeure.

\section{Background of the Study}

Construction industry like many other industries is subject to more risks due to the unique features and complexity of construction activities, such as long period, complicated processes, abominable environment, financial intensity and dynamic organization structures (Flanagan and Norman, 1993; Akintoye and MacLeod, 1997; Smith, 2003). Hence, evaluating estimating risk to manage risks associated with variable construction activities has never 
been more important for the successful delivery of a project.

Davies (2006) asserted that "construction projects are subject to risks at all stages of their development. Planning permission can be hard to obtain and designs may not be finalized before work starts. These risks can be managed, minimized, shared, transferred or accepted but it cannot be ignored (Latham 1994). Traditionally, the focus has been on quantitative risk analysis based on estimating probabilities and probability distributions for time and cost analysis. However, dissatisfaction arising from the inability of this type of approach to handle subjectivity in risk assessments has led to research into the use of other approaches. A favored current approach is for organizations to use risk quantification and modeling as vehicles to promote communication, teamwork and riskresponse planning amongst multidisciplinary project team members (Tar and Carr, 1999).

However, communication of construction project risks tends to be poor, incomplete and inconsistent, both throughout the construction supply chain and through the full project lifecycle. Even when risk management is carried out, the tendency is for it to be performed on an un-formalized ad hoc basis, and it appears to be dependent on the skills, experience and risk-orientation of individual key project participants. This lack of formality and the use of risk management by individuals mean that the adoption of different methodologies and terminologies is not unusual. This can result in the use of different methods and techniques for dealing with risk identification, analysis and management, producing different and conflicting results. Identified risks are not rigorously examined and, even when they have been assessed and remedial measures agreed upon, they are not generally communicated effectively throughout the supply chain. As a result of this, project participants do not have a shared understanding of the risks that threaten a project and, consequently, they are unable to implement effective early warning measures and mitigating strategies to adequately deal with problems resulting from decisions that were taken elsewhere in the chain. Part of the problem is the lack of a common language and process model in which risks and remedial measures may be identified, assessed, analyzed and dealt with in a defined way (Tar and Carr, 1999). It is clear that the success of a project is dependent on the extent to which the risks that affect it can be measured, understood, reported, communicated and allocated accordingly. It is believed that the development of a common language for describing risks will lead to a greater degree of consistency in the treatment of construction risks and to a greater understanding of their consequences for projects and organizations.

\section{Problem Statement}

Usta (2005) as cited in Onukwube (2009) observe that, it is pretty difficult to estimate productivity level and potential delays without a basis for making the estimate. He asserted further that rather than include contingency, contractors adjust their productivity rates or unit costs to reflect anticipated difficulties. In design and build or construction management it is common to add additional sums for unknowns and difficulties. This form of contingency is not allocated to overall project risk but for specific work related risks. The submission was supported by Laryea and Hughes (2009) in a research carried out in Ghana where similar trend is being experienced by reporting that risk allowances made by contractors in their estimates seemed to be guided by concerns about competition and winning the job rather than the true cost of risk.

Odeyinka (2006) observed that estimating risk in construction as a variable in the construction process whose variation results in uncertainty as to the final cost, duration, and quality of the project. Odeyinka et al (2009) in a research conducted on the budgetary reliability of bills of quantities (BOQ) for procurement of building projects, opined that the difference between the budgeted cost and the final cost incurred differed greatly depending on project type. This is supported by Khumpaisal (2007) who focused on construction industry and opined that maximum possible risk to the contractor occurs in the Lump Sum contract in which the extent of the work is moderately well identified and the cost of the work is tendered as a non-possible change project. Young (1993) viewed a lump sum contract as a contract where an agreed price has been determined for the execution of the work and performance of the obligations by the parties before the execution of the contract. Taroun et al. (2011) posited that risk assessment is probably the most difficult component of the Risk Management process; it is potentially the most useful. Since the project considered for this research were public project executed using Lump Sum contract and the gap noticed was that contractors do not have a definite way of taking care of inherent risks in their pricing system, they are only concerned about winning contract (Laryea and Hughes, 2009). This hinders the performance of not only the contractor but also the project as it is evident by the spate of abandoned projects and adversarial or acrimonious relationship project stakeholders' exhibit (Aje, 2008).

Therefore, it becomes highly imperative to evaluate the impact of risk on contractor's tender sum with a view to ensuring efficient delivery of projects. To achieve this, the following questions require viable answers; what are the types of risks impacting on contractor's tender figure in public building? What significance does the risks have on contractor's tender figure in public building? What is the impact of risks on contractor's tender figure in public building? And does contractor put pricing variables into consideration while estimating?

\section{Risks in Construction}

Every human Endeavour involves risk and the success or failure of any venture depends crucially on how we deal with these risks (Dey and Ogunlana, 2004). Ogunsami, Salako and Ajayi (2011) also argued that risk occurs in every facet of human life and as such construction projects are not exempted from this as they are characterized by activities that are predisposed to different types of risks ranging from political risks to construction risk. According to Oxford Advanced Learner's Dictionary (1995) defines risk as the 'chance of failure or the possibility of meeting danger or of suffering harm or loss. In specific relation to construction, The Aqua Group (1990) define risk as 'the possible loss resulting from the difference between what was anticipated and what finally happened.' Common consequences of project risks are cost overruns, time overruns, poor quality, and disputes among the parties to a construction contract. Risk is an important issue to contractors as well as clients and consultants of the industry. However, the problems of risk assessment are complex and poorly understood in practice. According to 
Baloi and Price (2003) risk has different meanings to different people; the concept of risk varies according to viewpoint, attitudes and experience. Engineers, designers and contractors view risk from the technological perspective; lenders and developers tend to view it from the economic and financial side; health professionals, environmentalists, chemical engineers view risk from safety and environmental perspective. Cooper and Chapman (1987) cited in John and Peter (1997) define risk as exposure to the possibility of economic or financial loss or gain, physical damage or injury, or delay, as a consequence of the uncertainty associated with pursuing a particular course of action. Risk can also be defined as the uncertainty that exists as to the occurrences of some events (Odeyinka, 1999). Odeyinka (2006) described risk in construction as a variable in the construction process whose variation results in uncertainty as to the final cost, duration, and quality of the project. In the lights of these definitions he views risk as a psychological phenomenon that is meaningful in terms of human reaction and experiences and as an objective phenomenon that may or may not be recognized in terms of human reaction and experience.

According to Smith (1999), risks specific to a project are inter active and sometimes cumulative that they affect cost and benefits associated to the project. He submitted that risks in construction projects arise from a variety of sources; Environmental/political; Hazard/safety; Market; and Technical/functional. Fong (1987) and Odeyinka (2005) as cited in Odeyinka (2006 ) asserts that those generally recognized within the construction industry are continually faced with a variety of situations involving many unknowns, unexpected, frequently undesirable and often unpredictable factors that include timing schedule slippage of the project tasks, technological issues, peopleoriented issues, finance, managerial and political issues (Lockyer and Gordon, 1996).

Osama and Salman (2003) also highlighted three kinds of construction risks; financial where project exceeds its budget and endangers the financial health of the company, time and design -related. It has been generally established that in the execution of building project, the final contract sum often varies from the budgeted sum of the contract. This could either be a decrease or an increase to the original contract sum and sometimes it is due to the complex nature and time span required for the execution of building construction.

\section{Source of Estimating Risk}

Nworuh and Nwachukwu (2004) argued the following sources of risks as predominant in construction projects; risks of error in estimating, risks of delay caused by client, his representatives, nominated subcontractors as nominated supplier; risks due to inclement weather, risk of clients, financial failure, risk associated with cash-flow problems and risk associated with industrial relation. Since this risks and uncertainties are invariable present in most projects irrespective of their size, location and scope, a need has arise for a risk management approach as a prudent step to evaluate such risks and to stem their negative impacts on predefined projects objectives. Different contractual arrangements have its inherent risks. Lump Sum Contracting Risks include risk of Quantity takeoff, Work missed and not included in estimate, Subsurface conditions missed or improperly evaluated, Subcontractors only quoted partial scope of work while that of Unit Price Contracting Risks include; Overrun or underrun of quantities of work, Subsurface conditions missed or improperly evaluated. Therefore, the risks common to both Lump Sum and Unit Price Estimates are schedule, weather, type of construction, design details, labor conditions, site location, duration of project, familiar owner and contract language

Nworuh and Nwachukwu (2004) placed the responsibility of an adequate and proper evaluation of these risks on both the client and design advisers. Construction cost is conceived in this study as either initial contract sum or tender sum or as actual construction cost or the final account sum. According to Odeyinka (1999) initial contract sum comprises of site labour cost, material cost and contractor cost, plant and establishments charges. He concludes that initial and final contract sum are never the same due to inherent risk factor such as fluctuation, variation, re-measurement of provisional quantities, adjustment of provisional and prime cost and some other risk factors. Nworuh and Nwachukwu (2004) deduce that construction projects are expected to be actualized at budgeted costs because of their inclusion of all the foreseen and unforeseen costs inherent in construction projects.

Smith (1999) and Chapman and Ward (1997) submitted that generally, risk is viewed within the context of the probability of different outcomes and that the general attitude towards risk is its identification, evaluation, control and management. (Odeyinka and Iyagba, 2000; Nworuh and Nwachukwu, 2004) in same vein concluded that, the integration of risk management techniques into the estimation of construction projects' cost other than purely common sense and instinct would considerably curb cost overrun.

Construction is often cited as a highly risk prone business because of the unique nature of the industry and its projects. These peculiar factors include necessity to price product before production, competitive tendering as a means of awarding work, low fixed capital requirements, preliminary expenses, delays to cash-inflows, tendency to operate with too low a working capital, seasonal effects, fluctuations and their effects, Government intervention, activity related to development, uncertain ground conditions, unpredictable weather, no performance liability or long-term guarantees, etc. Construction projects are complex, have a long production cycle, involve the input of many participants, and must meet many standards and statutory regulations (Kwakye, 1997). The high business failure rates construction industry records may indicate that while the industry has learned to master building, it has yet to master risk. For many years, practitioners of the industry have relied on unsystematic mechanisms such as intuition and in-house techniques to value allowances for risk when estimating. Construction risks are often perceived as events that influence the traditional project triple constraint objectives of time, cost, and performance (including quality). While risk is defined as: the exposure to the chances of occurrences of events adversely or favourably affecting project objectives as a consequence of uncertainty, the risk event is seen as what might happen to the detriment or in favour of the project (Al-Bahar and Crandall, 1990).

\section{Research Method}


Laryea and Hughes (2008) asserted that "there is no detailed account on how contractors actually take account of risks when calculating prices for their bids" therefore the data for this research were primarily gathered through a survey using well structured questionnaire. By focusing on traditional procurement projects, the questionnaire was designed with three major parts. The first part asked for demographic information of the respondents. The second part required the respondents to express their perception toward the importance of 4 headings of construction estimating risks extracted from previous similar studies conducted in the USA (Kangari, 1995), UK (Elhag et al. 2005; Laryea and Hughes, 2008), Hong Kong (Ahmed et al., 1999; Chan and Au (2009) and Kuwait (Kartam and Kartam, 2001). Wong and Hui (2006) posited that categorizing risks serves as a useful aid to managing them and it should, however, be noted that his categorization is not specific to construction projects. The final part of the questionnaire attempted to capture the contractors pricing variables. The respondents were asked to identify the highest risks borne by the contractor under the four headings. In distributing the questionnaires convenience sampling method was adopted, 115 questionnaires was distributed in four of the six states in the North central geo-political zones and the Federal capital territory among professional in the Construction Industry which includes owners, contractors and consultants which was involved on the targeted projects. After close to three months of data collection period, the research assistants retrieved 92 usable questionnaires, representing $80 \%$ response rate which is considered high as against the assertion of Andi (2006) who stated that construction professionals in Indonesia are usually reluctant to participate in such a survey.

\section{Data Analysis}

\subsection{Occurrence and Impact of Estimating Risk on} Contractors Tender Sum

Relative importance index (RII) was employed for two purposes i.e. ranking and determination of significance of different factors of the collected data. The premise of decision for the ranking is that the factor with the highest relative index "RII" is ranked first and others in such subsequent descending order (Okoko, 2001). Factor analysis (using principal component extraction method) was employed to ascertain the underlying relationship among the pricing factors and to group those factors.

From questionnaire drawn, the occurrence and impacts of estimating risk were tagged in "section B" which focused on variables of design risk, financial risk, construction risk and political risk on contractor's tender figure.

The occurrence indices for 4 design risk variables are shown in Table 1.From the table defective design was the highest ranked with (RII) 0.65 , variations of work and Changes of original design were ranked second with (RII) 0.63 respectively and Deficiencies in description of work was ranked fourth with (RII) 0.58. The views of respondents were base on the extent of occurrence of these variables on contractor's tender figure. This results showed that when designs are defective it gives room to changes which may likely cause variation to the scope of the job and consequently lead to poor description of work which may be misleading to the contractor.

The views of respondents were base on the extent of occurrence of these variables on contractor's tender figure. Financial risk variables are shown in Table 2. Inflation was ranked highest with (RII) 0.68 , inadequate cash flow was ranked second also with (RII) 0.63 , exchange rate was also ranked third with (RII) 0.62, cost overrun due to schedule delay was ranked fourth with (RII) 0.59 and contractors default was ranked fifth with (RII) 0.58. Many of the contractors relied solely on bank loans to prosecute most of their contracts and the galloping nature of the inflationary trend is a major risk borne by them which in returns affects their cash flow, credit crunch could cause delay or non performance of the contractor and thus, hamper effective project delivery when the contractors defaults.

Table 1. Relative importance indices (RII) and Ranking (R) the extent of occurrence of design risk on contractor’s tender figure as perceived by the respondent

\begin{tabular}{lcc}
\hline Design risk variables & RII & Rank \\
\hline 1. Defective design & 0.65 & 1 \\
2. Variation of work & 0.63 & 2 \\
3. Changes of original design & 0.63 \\
4. Deficiencies in description of work & 0.58 \\
\hline
\end{tabular}


Table 2. Relative importance indices (RII) and Ranking (R) the extent of occurrence of financial risk on contractor's tender figure as perceived by the respondent

\begin{tabular}{lcc}
\hline Financial risk variables & RII & 0.68 \\
\hline 1. Inflation & 0.63 & 1 \\
2. Inadequate cash flow & 0.62 & 3 \\
3. Exchange rates & 0.59 \\
4. Cost overruns due to schedule delay & 4 \\
5. Contractors default & 0.58 \\
\hline
\end{tabular}

Based on the analysis of the respondents in table 3, 'contractor's competence' with (RII) (0.70) was ranked as having the greatest extent of occurrence on contractors' tender sum. Defective materials and poor performance of suppliers with (RII) 0.62 were ranked second respectively. Poor quality of work was ranked fourth with (RII) 0.57 , productivity of equipment ranked fifth with (RII) 0.56 and labor, material and equipment availability and unforeseen site condition were ranked sixth with (RII) 0.55. Lacks of competency on the part of contractors have been the bane of the industry in Nigeria, since the introduction of "Due Process" where contracts are given to lowest responsive tenderer. The spate of abandoned projects has been on the increase, this is because contractors are just pricing to win contracts with certain or inadequate addition for unforeseen risk which may lead to the use of inferior material, thus, affects the quality of the end product.
The occurrence indices for 5 political risk variables are shown in Table 4. Political uncertainty was ranked first with (RII) 0.66, inflation was ranked second with (RII) 0.63 , Changes in government regulations was ranked third with (RII) 0.62, permits and ordinances was ranked fourth with (RII) of 0.57 and force majeure was ranked fifth with (RII) 0.46. The political environment in Nigeria is too stormy whereby contracts are given to party faithfully as a compensation for their effort and once there is a change in government it becomes abandoned projects. So also, is the lack of stability in banks policy where the interest and inflation rates are galloping as a result of government regulations. Excessive and bureaucratic nature of getting approval for works is another hindrance capable of impacting on the estimate of contractors negatively.

Table 3. Relative importance indices (RII) and Ranking (R) the extent of occurrence of construction risk on contractor's tender figure as perceived by the respondent

\begin{tabular}{lcc}
\hline Construction risk variables & RII & Rank \\
\hline 1. Contractors competence & 0.70 & 1 \\
2. Defective material & 0.60 & 2 \\
3. Poor performance of supplier & 0.60 & 2 \\
4. Poor quality of work & 0.57 & 4 \\
5. Productivity of equipment & 0.56 & 5 \\
6. Labor, material \& equipment availability & 0.55 & 6 \\
7. Unforeseen site condition & 0.55 & 6 \\
\hline
\end{tabular}


Table 4. Relative importance indices (RII) and Ranking (R) the extent of occurrence of political risk on contractor's tender figure as perceived by the respondent

\begin{tabular}{llc}
\hline Political risk variables & RII & Rank \\
\hline 1. Political uncertainty & 0.66 & 1 \\
2. Banks policy & 0.63 & 2 \\
3. Changes in government regulations & 0.62 & 3 \\
4. Permits and Ordinances & 0.57 & 4 \\
5. Force majeure & 0.46 & 4 \\
\hline
\end{tabular}

The impact indices for 4 design risk variables are shown in Table 5. Defective design was ranked first with (RII) 0.75 , Deficiencies in description of work was ranked second with (RII) 0.73 , Variations of work was ranked third with (RII) of 0.72 and Changes of original design was ranked fourth with (RII) 0.68 , and. The views of respondents were base on the impact of these variables on contractor's tender sum. From the survey defective design had very critical impact on contractor's tender sum either positively or negatively. This is as result of inconclusive nature of designs as at the time of procuring the project, this in returns lead to discrepancies in the scope of the work which becomes source of variations or unnecessary reworks.
The views of respondents were base on the most frequent impact of financial risk variables on contractor's tender figure as shown in Table 6. Inflation was the highest ranked with (RII) 0.74 , inadequate cash flow was also ranked second also with (RII) 0.72 , and cost overrun due to schedule delay was ranked third with (RII) 0.69 , whereby exchange rate and contractors default were also ranked fourth with (RII) 0.67.The inflation rate in Nigeria is unstable, over few months it has moved from single digit to two digit figure and as such impact negatively on the estimate submitted by contractors. This is because most of the contractors rely on bank loans in executing contract works which invariably affects their cash flow and the resultant effects are overruns in cost and time schedule and possible default of the contractor.

Table 5. Relative importance indices (RII) and ranking (R) of impact of design risk on contractors tender figure as perceived by the respondent

\begin{tabular}{lcc}
\hline Design risk variables & RII & Rank \\
\hline 1. Defective design & 0.75 & 1 \\
2. Deficiencies in description of work & 0.73 & 2 \\
3. Variation of work & 0.72 & 3 \\
4. Changes of original design & 0.68 & 4 \\
\hline
\end{tabular}

Table 6. Relative importance indices (RII) and ranking (R) of impact of financial risk on contractors tender figure as perceived by the respondent

\begin{tabular}{lcc}
\hline Design risk variables & RII & Rank \\
\hline 1. Inflation & 0.74 & 1 \\
2. Inadequate cash flow & 0.72 & 2 \\
3. Cost overruns due to schedule delay & 0.69 & 3 \\
4. Exchange rates & 0.67 & 4 \\
5. Contractors default & 0.67 & 4 \\
\hline
\end{tabular}


Based on the analysis of the respondents in Table 7, lacks of competence on the part of the contractor with (RII) 0.70 was ranked as having the greatest impact on contractors' tender sum. The researcher concurs with the findings because when the contractor is competent he will certainly price low and is likely to price high if the reverse is the case. Defective materials was ranked second with (RII) 0.68, unforeseen site condition was also ranked third with (RII) 0.67, whereas poor performance of suppliers and labor, material and equipment availability with (RII) 0.64 were ranked fourth respectively. Poor quality of work was ranked fifth with (RII) 0.61 and productivity of equipment was ranked sixth with (RII) 0.58. When it becomes apparent that the contractor cannot probably finish the work based on the incompetence exhibited at bidding stage, he results in cutting corners by using substandard materials and hence, reduces the quality of the projects.

Table 8 shows their impact of political risk based on the ranking of Relative importance indices (RII). Political uncertainty and Changes in government regulations were ranked first with (RII) 0.67, this is because when political environments becomes polluted government introduces measure that may be unfavorable to contractors such as bid and performance bond which affects the cash flow of contractors. Force majeure or political unrest that greets change of government too which was ranked third with (RII) 0.65 have consequential effects of estimate submitted by contractors, permits and ordinances was ranked fourth with (RII) 0.60 , inflation was ranked fifth with (RII) 0.58 as having insignificant impact on the tender sums under political risk.

Table 7. Relative importance indices (RII) and ranking (R) of impact of construction risk variables on contractors tender figure as perceived by the respondent

\begin{tabular}{lcc}
\hline Construction risk variables & RII & Rank \\
\hline 1. Contractors competence & 0.76 & 0.68 \\
2. Defective material & 0.67 & 2 \\
3. Unforeseen site condition & 0.64 & 3 \\
4. Labor, material \& equipment availability & 0.64 & 4 \\
5. Poor performance of supplier & 0.61 \\
6. Poor quality of work & 0.58 \\
7. Productivity of equipment & 5 \\
\hline
\end{tabular}

Table 8. Relative importance indices (RII) and ranking (R) of impact of construction risk variables on contractors tender figure as perceived by the respondent.

\begin{tabular}{lcc}
\hline Political risk variables & RII & 0.67 \\
\hline 1. Political uncertainty & 0.67 & 1 \\
2. Changes in government regulations & 0.65 & 3 \\
3. Force majeure & 0.60 \\
4. Permits and Ordinances & 4 \\
5. Banks policy & 0.58 \\
\hline
\end{tabular}




\subsection{Condensation of Contractors Pricing Variables}

Factor analysis which is a data reduction technique that is used to discover patterns among the variations in values of several variables was used to condense a large number of variables of contractor's pricing. Factor analysis assumes that underlying dimensions or factors can be used to explain complex phenomena. Factor Structure of Principal Factors Extraction is shown in Table 9.

Table 9. Factor Structure of Principal Factors Extraction and Varimax Rotation on Contractors Pricing Factor Items

\begin{tabular}{lccc}
\hline Cumulative & Factor & Communality & $\%$ of \\
Number Item & Loading & $\mathrm{h}^{2}$ & Variance \% of Variance \\
\hline
\end{tabular}

Factor 1: characteristics of project initiation
2. Type of client
0.776
0.781
16. Fluctuation non-fluctuation contract
0.556
0.841
20. Profile of other competitors
0.504
0.837
$8.314 \quad 8.314$

Factor 2: Lack of Competency

28. Low management competency subcontractor

$0.594 \quad 0.749$

31. Incomplete or inaccurate cost estimate

0.554

0.824

$7.612 \quad 15.926$

\section{Factor 3: Lack of data base}

34. Unavailability of sufficient amount of Unskilled labour

$0.606 \quad 0.856$

39. Price inflation of construction materials.

0.809

41. High performance/ quality expectations

0.744

$7.167 \quad 23.093$

\section{Factor 4: Effect of design variation on} labour productivity
12. Labour productivity basis
0.764

23. Design variations

0.850

$6.754 \quad 29.847$

Factor 5: Government policy on wages rates of Contract due to client's variation
14. Likely trend in wages rates over the period of the contract
0.781
20. Variations by the client
0.500
0.841
35. Bureaucracy of government
0.573
0.837
$8.314 \quad 8.314$

Factor 6: construction program strategies for bidders

21. The total number of bidders

0.509

0.749

26. Unsuitable construction program

0.556

0.824

$7.612 \quad 15.926$

Factor 7: Availability of material

1. Material Availability

Factor 8: Condition of payment

8. Payment condition attached to the project
0.856

0.809

0.531

0.744

$7.167 \quad 23.093$ 
Table 9. Factor Structure of Principal Factors Extraction and Varimax Rotation on Contractors Pricing Factor Items (continued)

\begin{tabular}{lccc}
\hline $\begin{array}{l}\text { Cumulative } \\
\text { Number Item }\end{array}$ & $\begin{array}{c}\text { Factor } \\
\text { Loading }\end{array}$ & $\begin{array}{c}\text { Communality } \\
\mathrm{h}^{2}\end{array}$ & $\begin{array}{c}\text { \% of } \\
\text { Factor 6: construction program strategies } \\
\text { for bidders }\end{array}$ \\
$\begin{array}{l}\text { 21. The total number of bidders } \\
\text { 26. Unsuitable construction program }\end{array}$ & 0.509 & 0.749 & \\
\hline
\end{tabular}

Factor 7: Availability of material

1. Material Availability $\quad 0.713 \quad 0.856$

\section{Factor 8: Condition of payment}

0.809

8. Payment condition attached to the project

0.531

0.744

$7.167 \quad 23.093$

Factor 9: Clients obligation

3. The financial capability of client

$0.636 \quad 0.764$

4. The risk involved in the project

0.562

0.850

6.754

29.847

Factor 10: Due process

24. Excessive approval procedure in administrative government departments.

0.502

\section{Factor 14: Company's manpower and} resources

10. The technical man power and equipment of the company

\subsection{Meanings Of The Contractors Pricing Factors}

\section{- Characteristics of project initiation (Factor 1) :}

This factor consists of three items that focus on the characteristics of project initiation. Characteristic of project initiation includes the type of client, the competency of other competitors and the fluctuation and non- fluctuation contract.

\section{- Lack of Competency (Factor 2) :}

There are two items in this factor that examine low competency of subcontractor and inaccurate estimate in the side of the contractors

\section{- Lack of data base (Factor 3) :}

In this factor, there are three items that focus on lack of data base. This includes unavailability of unskilled labour and price inflation of construction materials. To ensure contractors price, high performance/quality expectation is needed.

- Effect of design variation on labour productivity (Factor 4) :
Two items comprise the elements of factor 4 regarding the effect of design variation on labour productivity when pricing. This includes labour productivity basis and design variations.

- Government policy on wages rates on the influence of client variation (Factor 5$)$ :

There are three items in this factor 5 which emphasize on government policies on wages rates on the influence of client variation. This includes trend in wages rates over the period of the contract, variation by client and bureaucracy of government.

\section{- Construction program strategies for bidders (Factor} 6) :

This factor has two items pertaining to construction program strategies for bidders. The total number of bidders and unsuitable construction program.

\section{- Availability of material (Factor 7) :}

Factor 7 is composed of one item that explains material availability when pricing.

\section{Condition of payment (Factor 8) :}


This factor 8 explains the payment condition attached to the project.

\section{Clients Obligation (Factor 9) :}

In factor 9 there are two items which includes the financial capability of client and the risk involved in the project.

\section{Due process (Factor 10) :}

Factor 10 is composed of one item which explains the excessive approval procedures in administrative government departments.

\section{Company manpower and resources (Factor 14) :}

This factor explains the technical man power and resources of the company.

\subsection{Discussion of Findings}

The discussion is based on the impact of estimating risk on contractors' tender sum analyzed above, from the distributed questionnaires in some selected states in the Northern Nigeria. Relationships were drawn between the observed information through the analysis and past studies relevant to the research work. This research considered four factors under design risk which may likely impact on the tender sum negatively and it revealed that defective design had the greatest impact. These results agreed with the previous research results of Lemos, et al., (2004); Shen (1997) and Kartam and Kartam (2001) and Onukwube et al., (2009). It was also noticed that contractors are more concerned about defective design issues because they could be held responsible should any major issues arise due to incorrect design. Respondents also ranked the risks due to deficiencies in description of work, incessant variation in the scope of work and lack of coordination in design due to changes as high significance risks. The high ranking of the risks may be as result of undocumented change orders, lower work quality and misinterpretation drawings and specifications respectively, Enshassi et al., (2008) submitted that design changes, difference between actual and contract quantities and a rushed bidding process increase the risk borne by the contractor during estimating. Bala and Ibrahim (2007) also submitted in agreement to the previous researchers finding that inadequate or defective design could result to an upsurge of $43 \%$ in initial contract sum which is part of the risk borne by the contractor which may not be wholly transferred to the contractor. These risks can be tackled by paying genuine attention during design interface and ensure coordination of design correctly between design teams.

The analysis carried out on financial risks showed that Inflation, inadequate attention to cash flow are the major risks identified under financial risk that have significant impact on contractors estimate. Enshassi et al. (2006) opined that contractors could fail financially due to the following reasons: Dependence on banks and paying high rates; Lack of capital; Lack of experience in the line of work; Cash flow management; Low margin of profit due to competition; Lack of experience in contracts; Award contracts to lowest price; Closure. Argenti (1976) supported the assertion that small firms don't pay as much attention to financial ratios as do larger firms. It was stressed further that Small firms do not have an accounting department that publishes reports on a regular basis and thus, their financial ratios are difficult to monitor since they employ the services of private accountants. Enshassi et al. (2006) affirms the opinion further by agreeing that small firms never put into cognizance the benefit of the employees and compensations, variation orders, controlling equipment cost and usage, material wastages and yearly evaluating profits as a priority which may affect the financial situation of the company.

These results indicated lack of competence on the part of the contractor as the most significant factor impacting on their estimate under construction risks and also defective materials as major concerns to a contractor which was supported by the results of Ahmed et al. (1999) which considered the risks of defect materials as very important risks. Onukwube et'al, (2009) asserted that contractors competence had the highest impact on contractor's tender sum and but was ranked low by Salihudin et al. (2009). Poor quality of works, cost overruns as a result of schedule delay was also identified by this research as part of variables that exhibited significant impact on contractors' estimate as opined by Ogunsanmi et al. (2011) in their research carried out to develop Risk Classification Model for Design and Build Projects which reported that time overrun, cost overrun and poor quality are the most important factors in the function of the model.

Enshassi et al. (2006) in their research carried out in the gaza strip to determine the risks factors that may lead to contractor's business failure, reported that the political group factors as the most critical. The research also ranked political uncertainty and changes in government regulations high, followed by impact on contractor's tender sum which was in line with the assertion made by Salihudin et al., (2009). The results of the analysis carried out on the factors to be considered by contractors when pricing revealed, type of client as the most significant factor with the highest loading factor.

\section{Conclusion}

The paper examined the estimating risk on contractor's tender figure for public building projects in Nigeria with a view of ensuring effective project delivery. The research concludes thus that defective design has the greatest occurrence this is because mostly public projects are mostly procured when the designs are inconclusive and showed most significant impact on contractor's tender sum. Inflation has negative impacts on the contractor's tender sum. Lack of competence of contractor has negative impact on contractor's tender sum. Political uncertainty exhibited the most occurrences whereas changes in government regulation had the greatest impact on contractor's tender figure. The factors analysis precipitated likely trend in wages rates over the period, excessive approval procedure in administrative government department, the technical manpower and equipment of the company as well as unavailability of sufficient amount of unskilled labour to be most significant factors being considered by the contractor while estimating pricing risk.

It is recommended that competent contractors should be allowed to tender so as to see the incidence of these estimating risks as an important aspect that requires attention while evaluating contractor's tender sum and their concerns should not be about competition and winning the job alone rather than the true cost of risk. Construction companies should consider inherent 
estimating risk factors by adding a risk premium to quotation and time estimation. This trend has to be supported by public client and other stakeholders in the construction sector. The construction professionals should be aware of these estimating risk factors and follow the procedure of risk management for their proposed project to be actualized as budgeted. Training courses should also be provided for engineers and project managers on how to deal and minimize risks in building projects. Contractors should endeavor to understand the influence of pricing variables which could result into financial failure by practicing a stern cash flow management and minimizing the dependence on bank loans.

\section{References}

Ahmed, S. M., Ahmad, R. and De Saram, D. D. (1999). Risk management trends in the Hong Kong construction industry: a comparison of contractors and owners perception. Engineering, Construction and Architectural Management, 6(3), 225- 234.

Aje, I. O. (2008). The impact of contractor's prequalification and criteria of award on construction project performance in Lagos and Abuja, Nigeria. Unpublished PhD thesis, Federal University of Technology, Akure.

Akintoye, A. S. and MacLeod, M. J. (1997). Risk Analysis and Management in Construction. International Journal of Project Management, 15(1), 31-38.

Al-Bahar, J. F. and Crandall, K. C. (1990). Systematic risk management approach for construction projects. Journal of Construction Engineering and Management, 116(3), 533-546.

Andi (2006). The importance and allocation of risks in Indonesian construction projects. Construction Management and Economics, 24, 69-80.

Argenti, J. (1976). Corporate Collapse, UK: John Wiley and Sons.

Bala, K. and Ibrahim, Y. (2007). Effects of Inadequate Design by Specialist consultants in Construction Projects. Journal of Engineering and Applied Sciences, 2(9) 1414-1420

Baloi, D. and Price, A. D. F. (2003). Modelling global risk factors affecting construction cost performance. International Journal of Project Management, 21, 261-269.

Baloi, D. and Price, A. D. F. (2003). Modelling global risk factors affecting construction cost Performance. International Journal of Project Management, 21, 261-269.

Chan, E. H. W. and Au, M. C. Y. (2009). Factors Influencing Building Contractors' Pricing for TimeRelated Risks in Tenders. Journal of Construction Engineering and Management, 135(3), 135-145.

Chapman, C. B. and Ward, S. (1997). Project risk management, New York: Wiley.

Chapman, C. and Ward, S. (2004). Why risk efficiency is a key aspect of best practice projects. International Journal of Project Management, 22, 619-632.

Davies, J. (2006). Risk transfer in private finance initiative (PFIs) An economic analysis. Industrial Economic and Statistics Directorate (working paper).

Dey, P. K. and Ogunlana, S. O. (2004). Selection and application of risk management tools and techniques for build-operate-transfer projects. Industrial Management and Data Systems, 104(4), 334-346.
Elhag T. M. S., Boussabaine A. H., Ballal, T. M. A. (2005). Critical determinants of construction tendering costs: Quantity surveyors' standpoint. International Journal of Project Management, 23, 538-545.

Enshassi, A. S. Mohamed and Abu Mosa, J. (2008). Risk management in building projects in Palestine: contractors' perspective. Emirates Journal for Engineering Research, 13(1), 29-44.

Enshassi, A., Hallaq, K. and Mohamed, S. (2006). Causes of contractors' business failure in developing countries: the case of Palestine. Journal of Construction in Developing Countries, 11 (2), 1-14.

Flanagan, R. and Norman, G. (1993). Risk Management and Construction, Blackwell Science Ltd, London.

John, A. and Peter, D. (1997). Risk analysis and management for major construction projects. Proceeding of the RICS Foundation Construction and Building Research, Cobra, 1-35.

Joshua, O. D. and Jagboro, G. O. (2007). An evaluation of the impact of risk on project cost overrun in the Nigerian construction industry. Journal of Financial Management of Property and Construction, 12(1), 3744.

Kangari, R. (1995), Risk Management and Trends of US Construction. Journal of Construction Engineering and Management, 422-429.

Kartam, N. and Kartam, S. (2001). Risk and its management in the Kuwaiti construction industry: A contractors' perspective. International Journal of Project Management, 19, 325-335.

Khumpaisal, S. (2007). Risks in the Construction Project Procurement Process and the Mitigation Methods. Journal of Architectural/Planning Research and Studies, 5(2), 135-145

Kwakye, A. A. (1997). Construction Project Administration in practice, Longman Ltd. London.

Laryea, S. and Hughes W. (2008). How contractors price risk in bids: theory and practice. Construction Management and Economics, 26, 911-924.

Laryea, S. and Hughes, W. (2009). How contractors in Ghana include risk in their bid prices. In: Dainty, A. (Ed) Procs 25th Annual ARCOM Conference, 7-9 September 2009, Nottingham, UK, Association of Researchers in Construction Management, 1295-1304.

Latham, M. (1994). Constructing the Team. Final Report on Joint Review of Procurement and Contractual Agreements in the UK Construction Industry, HMSO, London.

Lemos, T., Eaton, D., Betts, M., Tadeu de Almeida, L. (2004). Risk management in the Lusoponte concession-a case study of two bridges in Lisbon, Portugal. International Journal of Project Management, 22, 63-73.

Lockyer, K. and Gordon, J. (1996). Project Management and Project Network Techniques, E\&FN Spore, London.

Makui, A., Mahdavi, I. and Farrokhian, F. (2009). A Model for Sharing the Costs of Uncontrollable Risks among Contracting Parties. Journal of Industrial and Systems Engineering, 3( 2), 125-139.

Nworuh, G. E. and Nwachukwu, G. O. (2004). Risk Management Approach to Claims in Construction Contract Administrations. The Quantity Surveyor Journal, 46(1), 24-31.

Odeyinka H. A., Oladapo, A. A., and Akindele, O. (2006). Assessing risk impacts on construction cost. Proceedings of the annual research conference of the 
royal institution of chartered surveyors, Cobra, University college London, 1-13.

Odeyinka, H. A. (1999). An Evaluation of the Use of Insurance in Managing Construction Risks. Journal Construction Management and Economics, London, 519-524.

Odeyinka, H. A. and Iyagba, R. I. (2000). Risk Management to Avoid Cost Overrun. The Quantity Surveyor Journal, 31(1), 14-21.

Odeyinka, H.A., Kelly, S. and Perera, S. (2009). An Evaluation of the Budgetary Reliability of Bills of Quantities in Building Procurement. The construction and building research conference of the Royal Institution of Chartered Surveyors, University of Cape Town, 435-446

Ogunsanmi, O. E., Salako, O. A., and Ajayi, O. M. (2011). Risk Classification Model for Design and Build Projects. Journal of Engineering, Project, and Production Management, 1(1), 46-60.

Okoko, E. (2001). Quantitative Techniques in Urban Analysis. Ibadan; Kraft Books Limited.

Onukwube, H., Adenuga, A. and Enang, I. (2009). The impact of risk on contractors pricing: a study of building projects in Lagos state, Nigeria. The construction and building research conference of the Royal Institution of Chartered Surveyors, University of Cape Town, 114-127.

Osama, A. J. and Salman, A. (2003). Risk Assessment in Construction. Journal of Construction Engineering and Management, 129(5), 492-500.

Perry, J. G. and Hayes, R. W. (1985). Risk and its Management in Construction Projects. The Institution of Civil Engineers Proceedings, 1(78), 499-522.

Salihudin, H., Mohd, S. J. and Saiful, A. H. S. (2009). The Contractor Perception Towers Industrialised Building System Risk in Construction Projects in Malaysia. American Journal of Applied Sciences, 6 (5), 937-942.

Shen, L. Y. (1997). Project risk management in Hong Kong. International Journal of Project Management, $15,101-105$.

Smith, N. J. (1999). Managing Risk in Construction Projects. Blackwell Science, Oxford.

Smith, N. J. (2003). Appraisal, Risk and Uncertainty (Construction Management Series), London: Thomas Telford Ltd, UK.

Tar, J. H. M. and Carr, V. (1999). A Proposal for Construction Project Risk Assessment Using Fuzzy Logic. Construction Management and Economics, London, 491-500.

Taroun, A., Yang, J. B. and Lowe, D. (2011). Construction Risk Modelling and Assessment: Insights from a Literature Review. The Built \& Human Environment Review, 4(1), 87-97.

The Aqua Group (1999). Tenders and contracts for building. 3ed. London: Blackwell science. The Oxford Encyclopaedia of Economic History (2003). 1, 504521.

Thompson, P. and Perry, J. G. (1992). Engineering Construction Risks. Thomas Telford, London.

Wong, J. T. Y. and Hui, E. C. M. (2006). Construction project risks: further considerations for constructors pricing in Hong Kong. Construction Management and Economics, 24, 425-438.

Young, W. A. (1993). Risk Apportioning in Engineering and Building Contracts in Australia. Masters of
Engineering Thesis, Civil and Building Engineering. Victoria University of Technology, Footscray.

Oyewobi Luqman Oyekunle is a Lecturer II in the

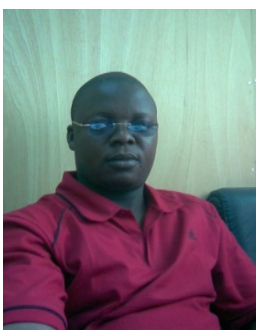
Department of Quantity Surveying, School of Environmental Technology, Federal University of Technology, Minna, Niger State, Nigeria. He holds HND, B.Tech (Hons) and M.Tech all in Quantity Surveying. He is a cooperate member of the Nigerian Institute of Quantity Surveyors and also a Registered Quantity Surveyor with the Quantity Surveyors Registration Board of Nigeria. He is currently studying for his $\mathrm{PhD}$ in Quantity Surveying and his research interests include Project performance Measurement, Stakeholders Management and Project procurement.

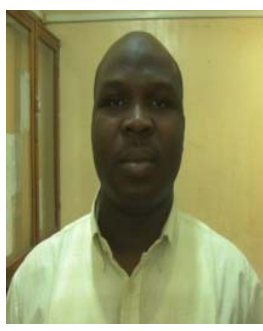

Ahmed Doko Ibrahim is a Senior Lecturer and Head of Quantity Surveying Department, Ahmadu Bello University, Zaria, Nigeria. He holds BSc (Hons) in Quantity Surveying, MSc in Construction Engineering \& Management and $\mathrm{PhD}$ in Construction Project Management. Dr. Ibrahim has research interest in the general areas of Quantity Surveying and Project Management with particular emphasis on Procurement, Cost Modelling, Public-Private Partnerships, Risk Management and Strategic Management of Construction firms. Dr Ibrahim is a corporate member of the Nigerian Institute of Quantity Surveyors, Association for Project Management (UK), Chartered Institute of Building (UK) and the Society for Construction Industry Arbitrators (Nigeria).

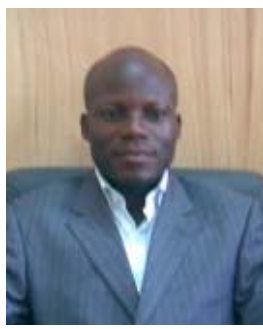

Bashir Olanrewaju Ganiyu is a Lecturer II in the Department of Quantity Surveying, Federal University of Technology Minna, Nigeria. He holds B.Tech(Hons) in Quantity Surveying and Msc. in Construction Management. $\mathrm{Mr}$ Ganiyu research interest in Construction Economics \& Management, Cost Modeling and Performance Evaluation. Mr. Ganiyu is a Corporate Member of The Nigerian Institute of Quantity Surveyors (NIQS) and he is a Registered Quantity Surveyor (RQS), having registered with Quantity Surveyors Registration Board of Nigeria (QSRBN). 